\title{
DÜBLIN
}

Technological University Dublin

ARROW@TU Dublin

Articles

School of Food Science and Environmental

Health

2010

\section{Effect of Ultrasonic Processing on Food Enzymes of Industrial Importance}

\author{
Paula Bourke \\ Technological University Dublin, paula.bourke@tudublin.ie \\ Brijesh Tiwari \\ University College Dublin \\ Colm O Donnell \\ University College Dublin, colm.odonnell@ucd.ie
}

See next page for additional authors

Follow this and additional works at: https://arrow.tudublin.ie/schfsehart

Part of the Food Processing Commons

\section{Recommended Citation}

Bourke, P., Tiwari, B., O'Donnell, C. and Cullen, P. J. Effect of ultrasonic processing on food enzymes of industrial importance. Trends in Food Science and Technology, Vol. 21, Issue 7, 2010. http://dx.doi.org/ 10.1016/j.tifs.2010.04.007

This Article is brought to you for free and open access by the School of Food Science and Environmental Health at ARROW@TU Dublin. It has been accepted for inclusion in Articles by an authorized administrator of ARROW@TU Dublin. For more information, please contact arrow.admin@tudublin.ie, aisling.coyne@tudublin.ie, gerard.connolly@tudublin.ie.

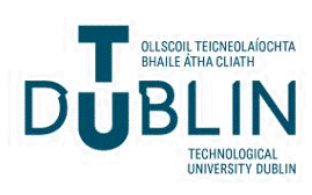




\section{Authors}

Paula Bourke, Brijesh Tiwari, Colm O Donnell, and Patrick Cullen

This article is available at ARROW@TU Dublin: https://arrow.tudublin.ie/schfsehart/129 
Dublin 1, Ireland. 


\section{Abstract}

In the last decade power ultrasound has emerged as an alternative processing option to conventional thermal approaches for pasteurisation and sterilisation of food products. While sonication alone is not adequate for inactivation of various spoilage and harmful enzymes present in food, ultrasound in combination with mild heat treatment and/or pressure has shown potential for both enzyme and pathogen inactivation. Numerous studies have investigated ultrasound for inactivating enzymes such as pectinmethylesterase, polyphenoloxidases and peroxidases responsible for deterioration of fruit \& vegetable juice and various enzymes pertinent to milk quality. The efficacy of ultrasound for the inactivation of enzymes in food is outlined in this review along with a description of the inactivation mechanism to elucidate the effect of ultrasound on important enzymes in fruit juices and dairy products. 


\section{Introduction}

Thermal treatment is the most common and widely employed pasteurisation and sterilisation technique for the inactivation of micro-organisms and enzymes in the food industry. Consumer demands for higher quality products have inspired researchers and the food industry to investigate novel processing technologies to replace traditional processing methods (Awuah, Ramaswamy, \& Economides, 2007). The application of the low frequency high power ultrasound $(\leq 0.1 \mathrm{MHz}, 10-1000$ W. $\mathrm{cm}^{-2}$ ) in the food industry has been widely investigated over the last decade. been extensively reviewed (Knorr, Zenkar, Heinz, \& Lee, 2004; Mason, Paniwnyk, \& Lorimer, 1996; McClements, 1995).

Power ultrasound has been reported to be sufficient to meet the FDA's mandatory $5 \log$ reduction of food borne pathogens in fruit juices. Ultrasound alone or in combination with mild temperature is reported to be effective against $E$. coli in model fluids (Salleh-Mack \& Roberts, 2007) and apple cider (Ugarte-Romero, Feng, Martin, Cadwallader, \& Robinson, 2006) and Listeria monocytogenes in apple cider (Baumann, Martin, \& Feng, 2005). Ultrasound alone or in combination with heat (thermosonication) or pressure (manosonication) or both heat and pressure (manothermosonication) is reported to be effective against various food enzymes pertinent to the dairy and fruit juice industry such as lipoxygenase, peroxidase, and polyphenol oxidase, as well as heat-resistant lipase and protease (López, Sala, de la Fuente, Condon, Raso, \& Burgos, 1994; López \& Burgos, 1995a,b; Vercet, Lopez, \& Burgos, 1997; Villamiel, \& de Jong, 2000). Inactivation of pathogenic and spoilage microorganisms or enzymes by sonication is mainly caused by physical (caviation, 
mechanical effects) and/or chemical (formation of free radicals due to sonochemical reaction) principles.

Sonication alone or in combination with thermal processing is reported to be effective against various other enzymes of industrial importance. Coakley, Brown \& James (1973) investigated the inactivation of alcohol dehydrogenase, catalase, and lysozyme

by exposure to $20 \mathrm{kHz}$ ultrasound in a model solution. They observed an exponential inactivation for alcohol dehydrogenase and lysozyme, however minor effects were observed for catalase. Conversely, Mañas, Muñoz, Sanz, \& Condón (2006) reported that sonication at ambient temperature and atmospheric pressure had no significant effect on the activation of lysozyme. However the desired inactivation was achieved at elevated temperatures $\left(60-80^{\circ} \mathrm{C}\right)$ and pressure $(200 \mathrm{kPa})$. The enzyme inactivation behaviour in real food systems may be considerably different due to presence of other food components. Kadkhodaee \& Povey (2008) investigated the inactivation of $\alpha$-amylase by thermosonication and reported a reduced activation energy $(19.27 \mathrm{~kJ} / \mathrm{mol} \mathrm{K})$ compared to thermal inactivation $(109 \mathrm{~kJ} / \mathrm{mol} \mathrm{K})$. They observed that the activation energy values for ultrasonic treatment were dependent on the emitting face of the probe and gas content of the medium. The effectiveness of ultrasound for control of enzymatic activity is strongly influenced by intrinsic and extrinsic factors such as enzyme concentration, temperature, the $\mathrm{pH}$ and composition of the medium. However, in some cases of enzyme inactivation using sonication, it is unclear whether this may attributed solely to the process of enzyme dissociation into subunits as observed with thermal inactivation.

Ultrasonic processing of fruit juices has minimal effects on the quality of fruit juices such as orange juice (Velero, Recrosio, Saura, Munoz, Martıc \& Lizama, 2007), guava juice (Cheng, Soh, Liew, \& Teh, 2007) and strawberry juice (Tiwari, 
O’Donnell, Patras, Brunton, \& Cullen, 2009a). It is also reported to enhance cloud value and stability of orange juice during storage (Tiwari, O'Donnell, Muthukumarappan, \& Cullen, 2009b). Recently, Piyasena, Mohareb \& McKellar (2003) and Jiranek, Grbin, Yap, Barnes \& Bates (2008) comprehensively reviewed the potential of ultrasound for inactivation of various food borne pathogens. Tiwari et al., (2008) reviewed the effect of ultrasound processing on quality of fruit juices. However, to date the effects of ultrasound on the inactivation of enzymes causing quality deterioration of food have not been comprehensively reviewed. The objective of this paper is to review recent literature on the potential of power ultrasound for the inactivation of enzymes of industrial importance in the dairy and fruit juice industries.

\section{Generation of power ultrasound}

Ultrasound is a form of vibrational energy in the frequency range of 20-100 kHz with a sound intensity of 10 to $1000 \mathrm{~W} / \mathrm{cm}^{2}$. Generally, power ultrasound employed in food processing uses lower frequencies (20 to $100 \mathrm{kHz}$ ) and causes cavitation with sound intensities of 10 to $1000 \mathrm{~W} / \mathrm{cm}^{2}$ (Feng and Yang 2005). The ultrasonic transducers convert electrical or mechanical energy to sound energy. There are three types of ultrasonic transducers in common usage including liquid-driven transducers, to large volume or processing liquid.

When high power ultrasound propagates in a liquid, cavitation bubbles will be generated due to pressure changes. These micro bubbles will collapse violently in the 
high localized temperatures up to $5,000 \mathrm{~K}$ and pressure of up to $50,000 \mathrm{kPa}$, resulting in high shearing effects (Mason, 1991; Piyasena et al., 2003) and a localized sterilization effect.

The ultrasound power level or energy transmitted to a food medium can be expressed as ultrasound power $(\mathrm{W})$, ultrasound intensity $\left(\mathrm{W} / \mathrm{cm}^{2}\right)$, acoustic energy density $(\mathrm{W} / \mathrm{mL})$ or cavitational intensity. The sonication treatment and the cavitation activity in a treatment chamber may vary for the same ultrasound intensity if the sample volume and probe location change. Recently, volumetric acoustic energy density $\left(\mathrm{W} / \mathrm{cm}^{3}\right.$ or $\left.\mathrm{W} / \mathrm{mL}\right)$ has been widely employed to indicate the ultrasonic power level.

Cavitation intensity can be estimated by measuring hydrogen peroxide $\left(\mathrm{H}_{2} \mathrm{O}_{2}\right)$ formation in distilled water during sonication following a catalyzed colorimetric procedure (Mead, Sutherland, \& Verrall, 1976). However, the determination of $\mathrm{H}_{2} \mathrm{O}_{2}$ generation during an ultrasound treatment in a food system is complex due to the presence of food components including ions and other colloidal components. To date, no reliable method to measure cavitation activity in a food system has been developed (Raviyan et al., 2005). Tsukamoto et al. (2004) reported that the measurement of ultrasound amplitude is an indication of the ultrasonic cavitation and is also a reliable method for indication of the ultrasound power.

Ultrasonic intensity or acoustic energy density can be determined calorimetrically (Mason et al., 1990) using Equations 1-3. The absolute ultrasonic power P is given as:

$$
P=m c_{p}\left(\frac{d T}{d t}\right)_{t=0}
$$

Where, $m$ is the mass, $c_{p}$ is the specific heat capacity and $(\mathrm{dT} / \mathrm{dt})$ is the rate of change of temperature during sonication which can be determined by polynomial curve fitting 

thermocouple. by (Mason et al., 1990)

$$
U I=\frac{4 P}{\pi D^{2}}
$$

Acoustic energy density or volumetric energy density can be determined by dividing absolute ultrasound power with the volume $(\mathrm{V})$ of the medium $\left(\mathrm{cm}^{3}\right.$ or $\left.\mathrm{mL}\right)$

$$
A E D=\frac{P}{V}
$$

\section{Mechanism of inactivation}

In general most studies reported that prolonged exposure periods were necessary to inactivate enzymes using high-intensity ultrasound. However some authors have reported that ultrasound has no impact on certain enzymes while others have demonstrated that acoustic cavitation induced by ultrasound waves both physically and chemically affects enzymes (Kadkhodaee \& Povey, 2008). Denaturation of protein is mainly responsible for inactivation of enzymes either by free radicals in sonolysis of water molecules $\left(\mathrm{H}_{2} \mathrm{O} \rightarrow \mathrm{OH}^{-}+\mathrm{H}^{+}\right)$or shear forces resulting from the formation or collapse of cavitating bubbles (Mason et al., 1994; Suslick, 1988).

The intensity of ultrasound applied, strongly influences the effect of sonication on enzyme activity. Researchers (Sakakibara, Wang, Takahashi, Takahashi, \& Mori 1996; Choi \& Kim, 1994) have reported that the activity of free enzymes increases under mild ultrasound irradiation. Selection of appropriate ultrasonic processing parameters can enhance enzymatic assisted processes. Şener, Apar \& Özbek (2006) 
increased the rate of lactose hydrolysis in milk using ultrasound at an acoustic power level of $20 \mathrm{~W}$, duty cycle of $10 \%$ and enzyme concentration of $1 \mathrm{~mL} / \mathrm{L}$, resulting in a minor loss $(25 \%)$ of enzyme activity. Application of ultrasound assists biochemical processes through reduced consumption of enzymes, shorter process times and improved uniformity of treatment (Basto, Tzanov, \& Cavaco-Paulo, 2007). Many mechanisms have been proposed for microbial and enzymatic inactivation in foods (Table 1). Cavitational intensity is the most widely reported inactivation mechanism. follows:

$\mathrm{H}_{2} \mathrm{O} \rightarrow \mathrm{OH}^{-}+\mathrm{H}^{+}$

$$
\mathrm{H}_{2} \mathrm{O}+\mathrm{OH}^{-}+\mathrm{H}^{+} \rightarrow \mathrm{H}_{2} \mathrm{O}_{2}+\mathrm{H}_{2}
$$
(Raviyan, Zhang, \& Feng, 2005). Cavitational activity decreases at higher temperatures due to a reduced cavitation threshold, resulting in lower temperatures and pressures upon bubble collapse (Mason \& Lorimer, 2002).

Reported inactivation mechanisms are directly or indirectly dependent on processing variables such as sonotrode type and geometry, frequency and acoustic energy density. Media properties including treatment volume and gas concentration also affect the efficiency of enzyme inactivation (Kadkhodaee \& Povey, 2008; Raso, Pagan, Manas, Pagan, \& Sala, 1999).

Özbek, \& Ülgen (2000) reported that ultrasonic inactivation mechanisms are specific to the enzyme under investigation and depend on amino acid composition and the conformational structure of the enzyme. For example manothermosonication is 
reported to inactivate peroxidase by splitting its prosthetic heme group, as for the mechanism of heat inactivation (Lopez \& Burgos, 1995a), whereas lipoxygenase appears to be inactivated by a free radical mediated mechanism (Lopez \& Burgos, 1995b) and possibly by denaturation of proteins (Mason, 1998). Some enzymes, such as catalase, yeast invertase, or pepsin are resistant to ultrasound (Sala, Burgos, Condon, Lopez, \& Raso, 1995).

\section{Fruit juice enzymes}

\section{Pectinmethylesterase}

Pectinmethylesterase (PME), an ubiquitous enzyme found in plants, hydrolyses pectin resulting in decreased cloud stability and reduced viscosity due to pectin chain degradation. Ultrasound was reported to inactivate PME in tomato juice and orange juice (Kuldiloke, 2002, López, Vercet, Sanchez, \& Burgos, 1998, Vercet, Lopez, \& Burgos, 1999 and Vercet, Oria, Marquina, Crelier, \& Lopez-Buesa, 2002) in combination with heat and/or pressure. López et al. (1998) reported that the $D$-value of tomato PME was reduced from $45 \mathrm{~min}$ for thermal treatment to $0.85 \mathrm{~min}$ for manothermosonication at the same temperature $\left(62.5^{\circ} \mathrm{C}\right)$. Raviyan et al. (2005) reported a similar reduction in D value from 1571.4 min for thermal treatment to < 80 min for thermosonication at the same temperature $\left(50{ }^{\circ} \mathrm{C}\right)$. The $\mathrm{D}$ value was further reduced from $240.6 \mathrm{~min}$ to $1.5 \mathrm{~min}$ with an increase in temperature from 50 to $61{ }^{\circ} \mathrm{C}$ at a cavitation intensity of $0.007 \mathrm{mg} \cdot \mathrm{L}^{-1} \cdot \mathrm{min}^{-1}$ (Raviyan et al. 2005). Wu, Gamage, Vilkhu, Simons, \& Mawson, (2008) reported a reduction in D value for PME inactivation at 60 and $65^{\circ} \mathrm{C}$ compared to those observed for thermal inactivation. However, they did not observe this synergy at $70{ }^{\circ} \mathrm{C}$, where the $\mathrm{D}$ values for thermal and thermosonication treatment were similar. 
A number of studies have reported that sonication in combination with either heat or pressure has a synergistic effect on PME inactivation. Raviyan et al., (2005) reported increased inactivation of PME in sonicated tomato juice for a temperature range of 50

$-72{ }^{\circ} \mathrm{C}$ compared to thermal treatment alone. Increased inactivation was dependent

on cavitational intensity which is reported to be temperature dependent. For example, simultaneous applications of heat $\left(72{ }^{\circ} \mathrm{C}\right.$ ) and ultrasound (frequency of $20 \mathrm{kHz}$ and amplitude of $117 \mu \mathrm{m})$ under moderate pressure $(200 \mathrm{kPa})$ increased the inactivation rate of orange juice PME by a factor of 25 in a buffer solution, and by more than a factor of 400 in orange juice (Vercet, Lopez, \& Burgos, 1999). Higher inactivation rates in juice could be either due to the presence of co-solutes (substrates or other molecules that physically interact with enzymes) or loss of the protective effect of pectin in orange juice to which PME is bound (Vercet, Lopez, \& Burgos, 1999). The effect of pectin on PME inactivation is also reported during orange juice ultrafiltration (Snir et al. 1995). Raviyan et al., (2005) reported that the increase in enzyme inactivation during thermosonication is more pronounced at lower temperatures. One possible explanation for this could be that at higher temperatures, increased vapour pressure inside the bubbles introduces a cushioning effect and hence produces less effective bubble collapse (Mason, 1990). Tiwari et al. (2008) concluded that sonication alone is not sufficient to inactivate PME. The maximum PME inactivation level reported for orange juice sonicated at the highest acoustic energy density of 1.05 $\mathrm{W} / \mathrm{mL}$ for 10 min was $62 \%$ (Figure 1 ).

The reduction of PME activity in sonicated lemon juice resulted in enhanced cloud stability during storage for 18 days at $4{ }^{\circ} \mathrm{C}$ compared to thermally processed lemon juice (Knorr et al. 2004). The improved cloud stability observed during storage could be due to the mechanical damage of the PME protein structure during sonication. 


\section{Polyphenoloxidase}

Polyphenoloxidase (PPO) is a copper-containing enzyme that causes enzymatic browning in fresh fruits and vegetables products such as juices. Enzymatic browning is one of the biggest problems faced during the processing of fruits and vegetables (Yemenicioglu \& Cemeroglu, 2003). PPO is not an extremely heat stable enzyme, and short exposure to temperatures between 70 and $90{ }^{\circ} \mathrm{C}$ is sufficient to inactivate it. Cheng et al. (2007) reported an increase in PPO in sonicated ( $35 \mathrm{kHz}$; for $30 \mathrm{~min}$ ) guava juice compared to control. They observed an increase in enzymatic activity possibly due to the processing conditions employed. Cheng et al (2007) employed a standard ultrasonic bath for inactivation studies. Sonication baths are generally of low power in order to avoid cavitational damage to the tank walls, consequently the acoustic energy density is low due to large volume. However, a low ultrasound power level as in this case can enhance the disruption of biological cell walls to facilitate the release of their contents, indeed many ultrasonic horn systems were first marketed as cell disruptors (Mason et al., 1996). Moreover, low power levels can induce stimulation of enzymes whereas, higher power levels inactivate enzymes due to denaturation.

A synergistic effect of heat and pressure with ultrasound has been reported for the inactivation of PPO in model buffer systems (Lopez et al., 1994). They reported a linear decrease in $\log \mathrm{D}$ values for an increase in ultrasound amplitude level over the range $35-145 \mu \mathrm{m}$. Heat or pressure assisted ultrasonic processing of juice can substantially reduce enzyme resistance and the heat treatment required for inactivation. As discussed earlier, the enzyme inactivation mechanism is complex and 
depends upon several factors such as fruit juice composition, enzyme type, $\mathrm{pH}$ and processing parameters.

\section{Peroxidases}

Peroxidase (POD) is a heme-containing enzyme which can be used to evaluate the efficiency of vegetable blanching (Lopez et al., 1994) because of its relatively high thermal stability. POD which is found in most raw and unblanched fruit and vegetables, is associated with the development of off-flavours and browning pigments. Thermosonication has been reported to reduce the blanching time required for inactivation of POD in watercress; for example to obtain 90\% POD inactivation at $90{ }^{\circ} \mathrm{C}$, a thermal treatment time of $70 \mathrm{~s}$ is necessary compared to $5 \mathrm{~s}$ for thermosonication treatment at the same temperature (Cruz, Vieira, \& Silva 2006). De Gennaro, Guerrero, Lopez-Malo, \& Alzamora (1999) reported first order inactivation

kinetics for POD during sonication. This could be due to the cushioning effect of cavitating bubbles which are formed under the tip of sonotrode, acting as a barrier to the solution during sonication (Ratoarinoro, Contamine, Wilhem, Berlan \& Delmas, 1995). Cruz et al., (2006) reported an increase in POD activity during blanching of watercress (Nasturtium officinale) for thermosonication in a temperature range of $40-$ $80{ }^{\circ} \mathrm{C}$ and a decrease in enzymatic activity at a higher temperature range of $82.5-$

$92.5{ }^{\circ} \mathrm{C}$. They observed a higher rate of inactivation for combined ultrasound and heat treatment compared to heat treatment alone. They reported an increase in the POD enzyme activity due to sonication at low temperatures, which could be related with the change of conformation of the enzyme to a higher enzyme-substrate interaction. Similarly the reduction in enzyme activity at higher temperatures could also be related 
system, found in watercress, is formed by a heat-labile fraction and a heat-resistant fraction. However, thermal inactivation of POD can be either by dissociation of the prosthetic (heme) group from the haloenzyme (active enzyme system), conformational changes in protein or by modification or degradation of the prosthetic group (Lemos, Oliveira, \& Saraiva, 2000). Inactivation of POD due to sonication results from conformational changes in protein and by splitting of prosthetic group from haloenzyme (Lopez \& Burgos, 1995a). It is difficult to identify the specific enzyme inactivation mechanism during sonication which could be due to a singular or combination of several chemical and physical effects occurring simultaneously (Table $1)$.

\section{Lipoxygenase}

Lipoxygenase (LOX) activity in fruit and fruit products is reported to be related to oxidation of fatty acids and pigments. LOX catalyzes the oxidation of polyunsaturated fatty acids containing a cis, cis-1,4-pentadiene system, which produces 9- or 13-cis, trans-hydroperoxides. LOX has been associated with quality deterioration because of its negative effects on pigments such as carotenes during storage, and its role in offflavour and odour production (King \& Klein, 1987; Aguiló-Aguayo, Sobrino-López, Soliva-Fortuny, \& Martín-Belloso, 2008). However, in fruit juices a minimum LOX activity may be desirable for long storage periods (Min, Min \& Zhang 2003). Thakur \& Nelson (1997) reported a 75 to $85 \%$ inactivation of LOX in soybeans by ultrasound. Inactivation was strongly dependent on $\mathrm{pH}$, treatment time and ultrasonic frequency. Similarly Lopez and Burgos (1995a) reported that the resistance of LOX against heat and manothermosonication was also $\mathrm{pH}$ dependent during sonication over an amplitude range of $0-104 \mu \mathrm{m}$ and a temperature range of $67.5-76.3{ }^{\circ} \mathrm{C} . \mathrm{pH}$ 
dependency is mainly due to the profound effects of $\mathrm{pH}$ on protein conformation with all enzymes having a maximum stability at an optimum $\mathrm{pH}$.

\section{Dairy Enzymes}

Sonication of milk is reported to result in a diversity of physicochemical changes in macromolecules including enzyme inactivation, homogenisation (Villamiel \& de Jong, 2000), reduction in fermentation time during yogurt preparation (Wu et al., (2001) and improvement of yoghurt rheological properties (Vercet et al., 2002). Applications of ultrasound in the dairy industry have been reviewed by Villamiel, van Hamerveld, \& de Jong (1999). Although many pathogenic and spoilage microorganisms are easily destroyed under standard heat treatments, many of them produce extracellular lipase and protease, which can withstand UHT treatment (Stead, 1986). These thermoresistant enzymes can reduce the quality and shelf-life of heat-treated milk and other dairy products. The simultaneous application of heat and ultrasound under pressure (manothermosonication) has been found to be more effective than heat treatment alone in the inactivation of heat resistant protease and lipase secreted by $P$. fluorescens (Vercet, López, \& Burgos 1997). The effect of ultrasound on enzymes involved in the coagulation of milk such as chymosin, pepsin, and several fungal enzymes has been studied in model systems using batch processes. In general, after long (several minutes) ultrasonic treatments, the proteolytic activity of the enzymes investigated decreased. However, when a mixture of milk and chymosin was sonicated, minimal enzyme inactivation was observed (Raharintsoa, Gaulard, \& Alais, 1977, 1978). It has been reported that enzyme inactivation increases with an increase in solids content and decreases with increase in enzyme concentration (Sala et al., 1995; Villamiel, \& de Jong, 2000). 
Villamiel \& de Jong (2000) outlined the effect of ultrasound on native milk enzymes

(Table 2). No effect on milk enzymes was observed when ultrasound was applied without thermal treatment. However inactivation effects were reported when sonication was carried out above $61{ }^{\circ} \mathrm{C}$. Differences observed in the inactivation of the native milk enzymes such as alkaline phosphatase, $\gamma$-glutamyltranspeptidase, lactoperoxidase, whey proteins ( $\alpha$-lactalbumin and $\beta$-lactoglobulin) in whole and skim milk were attributed to factors relating to the composition of the medium. Villamiel and Jong (2000) reported that the resistance of enzymes to sonication is both enzyme and media specific. Several studies have demonstrated that the effect of ultrasonic waves increases at higher total solids concentration (Santamaria, Castellani, \& Levi, 1952; Sala et al., 1995). In skim milk, the concentration of solids is lower than in whole milk resulting in a reduced ultrasonic effect. However, the concentration of enzymes in skim milk (alkaline phosphatase, AP and gamma glutamyl transpeptidase, GGTP) is also lower than in whole milk leading to a more pronounced effect, as these enzymes are linked to fat globules and can be liberated by the ultrasound effect to the serum phase. Whereas, lactoperoxidase (LPO) is located in the whey, and the main cause of the enhanced decrease of enzyme activity in whole milk than in skim milk by the effect of ultrasound and heat $\left(75.5^{\circ} \mathrm{C} ; 102.3 \mathrm{~s}\right)$ could be due to the higher concentration of solids in the former (Villamiel and Jong, 2000). Ertugay, Yuksel, \& Sengul (2003) reported greater inactivation of LPO and AP enzymes which have a significant function in dairy processing at $40{ }^{\circ} \mathrm{C}$ compared to $20{ }^{\circ} \mathrm{C}$ (Table 2$)$

The combination of sonication with heat can assist thermal processing by reducing the thermal resistance of various enzymes. Prolonged exposure to high- 
intensity ultrasound has been shown to inhibit the catalytic activity of a number of food enzymes due to the intense pressures, temperatures and shear forces generated by the ultrasonic waves which denature protein. However, in some cases, solutions containing enzymes have been found to have increased activity following short exposures to ultrasound (McClements, 1995). This may be due to the ability of ultrasound to break down molecular aggregates, making the enzymes more readily accessible for reaction, therefore the key enzymes of concern to each food system should be investigated to ascertain the critical control parameters which can be specific to the enzyme, the food system or both.

\section{Inactivation kinetics}

As discussed above enzyme inactivation by ultrasound is governed by various intrinsic or extrinsic factors. Predicted kinetic models should be able to establish, appropriate treatment conditions to achieve desired levels of microbial or enzymatic inactivation, facilitating the production of stable and safe foods (Mañas, \& Pagán, 2005). The inactivation of enzymes during sonication has been shown to follow first1999).

$$
\log _{e}\left(\frac{N_{t}}{N_{0}}\right)=-k t
$$

$$
\frac{d N_{t}}{d N_{o}}=a \exp \left(-k_{1} t\right)+(1-a) \exp \left(-k_{2} t\right)
$$


Where, $N_{0}$ is the initial enzymatic activity, $N_{t}$ is the enzymatic activity at time $t$

$(\min ) ; k\left(\min ^{-1}\right)$ is the inactivation rate constant; $k_{1} \& k_{2}$ are inactivation rate constants

for heat-labile isoenzyme fraction $(a)$ and a heat-resistant isoenzyme fraction $(1-a)$ respectively.

First order inactivation kinetic models are well established for describing enzyme inactivation during thermal treatments assuming the media is not comprised of multiple isozymes with different thermostabilities (Lopez et al., (1994). Deviations in enzyme inactivation from first order kinetics are due to the formation of enzyme aggregates with different heat stabilities. The monophasic inactivation of enzymes under manothermosonication may be attributed to the well established dissociation effect of ultrasonic waves on aggregates. Similar observations were observed by Vercet et al., (2001) for inactivation of proteases (phospholipase A2, trypsin, $\alpha$ chymotrypsin) and lipases during manothermosonication. They reported that the biphasic behaviour (Equation 5) observed in thermal inactivation approaches first order kinetics in manothermosonication inactivation. Kinetic mechanisms for inactivation of peroxidase enzymes have been proposed to explain the biphasic course of thermal inactivation of peroxidase (Henley \& Sadana, 1985). This phenomenon is generally accepted to be due to the presence of isozymes of different heat stability.

Cruz et al., (2006) employed a biphasic inactivation model (Equation 5) for the thermal inactivation of peroxidases in water cress, formed by a heat-labile isoenzyme fraction and a heat-resistant isoenzyme fraction. They showed that the dependencies of $k_{1}$ and $k_{2}$ on temperature followed the Arrhenius law and first order inactivation during thermosonication. Similar first order inactivation was reported by De Gennaro et al. (1999). However the authors did not observe any appreciable increase in the rate 
constant with respect to increase in power level. They employed an exponential decay curve to model the D value for enzyme inactivation (Equation 6).

$$
D_{t}=D_{\infty}+\left(D_{0}-D_{\infty}\right) e^{-\frac{P}{a}}
$$

Tiwari et al. (2008) reported that the fraction conversion model (Equation 7) adequately described the inactivation of PME in orange juice with respect to AED. A fraction conversion model is a special case of the first-order model which can be used when a fraction of the enzyme is not destroyed after prolonged treatment $\left(A_{\infty}\right)$ (Van den Broeck et al., 2000; Ly-Nguyen et al., 2003).

$$
\frac{\log \left(A_{t}-A_{\infty}\right)}{\left(A_{0}-A_{\infty}\right)}=-K_{F} t
$$

The fraction conversion model adequately described both the inactivation of the heat sensitive portion of the enzyme (thermolabile isoenzyme) along with the thermostable enzyme fraction.

\section{Status review}

Although the potential of power ultrasound has been investigated for many food applications, challenges remain prior to widespread adoption of the technology. One of the difficulties reported in the literature is the non-standardised reporting of methodology and control parameters. Comparable reporting in terms of energy density, probe types and sample volumes is required. Generally higher enzyme inactivation is reported for probe type systems compared with ultrasound baths. 
homogenization, crystalisation, extraction etc, however the synergistic effects on enzymes or vice versa are generally not reported. Validation of the technique for enzyme or microbial inactivation needs to deal with the complex nature of food systems, in particular non-Newtonian fluids and particulate matter. Recently, computational fluid dynamic (CFD) simulations have been employed to investigate the influence of fluid properties on the efficacy of various non-thermal food processing techniques, however this approach has not been widely adopted for ultrasound processing to date.

Despite promising effects of sonication alone or in combination with heat or pressure, scale-up also remains a significant challenge to industrial adoption. There are few detailed reported industrial scale uses of power ultrasound. For application of power ultrasound on an industrial scale, it is essential to have energy efficient processors. For food applications the design of the probe is paramount, non contact transducers or coated transducers where the construction material is non-reactive, with little or no erosion are required.

\section{Conclusion}

Ultrasound alone or in combination with heat and/or pressure can achieve the desired enzyme inactivation by reducing thermal resistance. Sonication efficacy is dependent upon numerous extrinsic and intrinsic control parameters. Ultrasound processing enhances enzymatic reactions at low power levels e.g. $\alpha$-amylase, invertase and amyloglucosidase for starch, sucrose and glycogen hydrolysis respectively (Barton, Bullock and Weir, 1996) and inactivation of spoilage enzymes e.g. PME, PPO at higher power levels. The lack of standardisation in ultrasound operating frequencies and power levels makes comparisons between different studies difficult. Consequently ambiguity arises within the literature, as these control conditions may 
not be reported in detail or are reported differently. Although the possibility of deactivating enzymes or microorganisms by ultrasonic processing has been demonstrated under laboratory conditions, industrial adoption of this technology is limited, due to the significant challenges encountered in industrial scale-up. Future research should be focused on the development of non-contact ultrasound transducers or sonication bath systems with variable frequencies and the investigation of the economic feasibility of sonication as a novel food processing and preservation technique.

\section{References}

Aguiló-Aguayo, I., Sobrino-López, Á, Soliva-Fortuny, R, \& Martín-Belloso, O (2008). Influence of high-intensity pulsed electric field processing on lipoxygenase and $\beta$ glucosidase activities in strawberry juice. Innovative Food Science \& Emerging Technologies, 9 (4), 455-462.

Awuah, G.B. Ramaswamy, H.S. \& Economides, A. (2007).Thermal processing and quality: Principles and overview. Chemical Engineering and Processing, 46 (6), 584-602.

Barton, S., Bullock, C. \& Weir, D. (1996). The effects of ultrasound on the activities of some glycosidase enzymes of industrial importance. Enzyme and Microbial Technology, 18(3), 190-194.

Basto, C., Tzanov, T., \& Cavaco-Paulo, A. (2007). Combined ultrasound-laccase assisted bleaching of cotton. Ultrasonics Sonochemistry, 14 (3), 350-354.

Baumann, A. R., Martin, S. E. \& Feng H. (2005). Power ultrasound treatment of Listeria monocytogenes in apple cider. Journal of Food Protection, 68, 2333-2340.

Cheng, L. H., Soh, C. Y., Liew, S. C \& Teh, F. F. (2007). Effects of sonication and carbonation on guava juice quality. Food Chemistry, 104, 1396-1401. 
474 Choi J.H. \& Kim, S.B. (1994). Effect of ultrasound on sulphuric acid-catalysed hydrolysis of starch, Korean Journal of Chemical Engineering, 11(3), 178-184.

Coakley, W T., R. C. Brown and C. J. James, (1973). The inactivation of enzymes by ultrasonic cavitation at $20 \mathrm{kHz}$. Archives of Biochemistry and Biophysics, 159 722729.

Cruz, R.M.S., Vieira M.C. and Silva, C.L.M. (2006). Effect of heat and thermosonication treatments on peroxidase inactivation kinetics in watercress (Nasturtium officinale), Journal of Food Engineering, 72 (1), 8-15.

De Guerrero S, López-Malo A \& Alzamora SM. (2001). Effect of ultrasound on the survival of Saccharomyces cerevisiae: influence of temperature, $\mathrm{pH}$ and amplitude. Innovative Food Science and Emerging Technologies, 2, 31-39. International, 58 (11-12), 593-595.

Feng H, Yang W. 2005. Power ultrasound. In: Hui YH, editor. Handbook of food science, technology, and engineering. New York: CRC Press. 3632 p. and Technology, 41(4), 604-610.

Guerrero, S., Lopez-Malo, A., and Alzamora, S.M. (2001). Effect of ultrasound on the survival of Saccharomyces cerevisiae: influence of temperature, $\mathrm{pH}$ and amplitude, Innovative Food Science \& Emerging Technologies, 2, 31-39.

Henley, J. P. and Sadana, A. (1985). Categorization of enzyme deactivation using series-type mechanism. Enzyme and Microbial Technology, 7, 50-60. 
498 Jiranek, V., Grbin, P., Yap, A., Barnes, M., \& Bates, D. (2008). High power ultrasonics as a novel tool offering new opportunities for managing wine microbiology, Biotechnology Letters, 30, 1-6.

501

502

503

504

505

506

507

508

509

510

511

512

513

514

Kadkhodaee, R. and Povey, M.J.W. (2008). Ultrasonic inactivation of Bacillus $\alpha$-amylase. I. effect of gas content and emitting face of probe. Ultrasonics Sonochemistry, 15(2), $133-142$.

Kashkooli, H., Roony J. and Rooxby, R. (1980). Effects of ultrasound on catalase and malate dehydrogenase, Journal of Acoustic Society of America, 67, 1789-1801.

King D.L. and Klein, B.P. (1987). Effect of flavonoids and related compounds on soybean lipoxygenase-1 activity, Journal of Food Science, 57(1), 220-221.

Knorr, D., Zenker, M., Heinz, V. \& Lee, D. (2004). Applications and potential of ultrasonics in food processing, Trends in Food Science \& Technology, 15(5), 261-266.

Kuldiloke, J. (2002). Effect of ultrasound, temperature and pressure treatments on enzyme activity and quality indicators of fruit and vegetable juices. Doctoral dissertation, Technical University of Berlin, 2002.

Lehmann, J.F. and Krusen, F.H. (1954). Effect of pulsed and continuous application of ultrasound on transport of ions through biologic membranes. Archives of Physical Medicine and Rehabilitation, 35(1), 20-23.

Lemos, M.A., Oliveira J.C. and Saraiva, J.A. (2000). Influence of pH on the thermal inactivation kinetics of horseradish peroxidase in aqueous solution, LWT Food Science and Technology, 33, 362-368.

López, P.\& Burgos, J. (1995a). Lipoxygenase inactivation by manothermosonication: effects of sonication physical parameters, $\mathrm{pH}, \mathrm{KCl}$. Sugars, glycerol and enzyme concentration. Journal of Agricultural and Food Chemistry, 43, 620-625. 
López, P.\& Burgos, J. (1995b). Peroxidase stability and reactivation after heat treatment and manothermosonication. Journal of Food Science, 60, 451-455.

Lopez, P., Sala, F.J., de la Fuente, J.L., Condon, S., Raso, J., \& Burgos, J. (1994). Inactivation of peroxidase, lipoxygenase and polypohenol oxidase by manothermosonication. Journal of Agricultural and Food Chemistry, 42, 252-256.

López, P., Vercet, A., Sa'nchez, A. C., \& Burgos, J. (1998). Inactivation of tomato pectic enzymes by manothermosonication. Zeitschrift fur Lebensmittel-Untersuchung und Forschung, 207, 249-252.

Ly Nguyen, B., Van Loey, A.M., Smout, C., Eren Özcan, S., Fachin, D., Verlent, I., Vu, S., Duvetter, T. \& Hendrickx, M.E., (2003). Mild-heat and high-pressure inactivation of carrot pectin methylesterase: A kinetic study. Journal of Food Science, 68, 13771383. Journal of Applied Microbiology, 98, 1387-1399.

Mañas, P., Muñoz, B. ., Sanz, D. and Condón, S. (2006). Inactivation of lysozyme by

Mañas, P., \& Pagán, R. (2005). Microbial inactivation by new technologies of food preservation. ultrasonic waves under pressure at different temperatures. Enzyme and Microbial Technology, 39 (6), 1177-1182.

Mason, T. J. \& Lorimer, J. P. \& Baters, D. M. (1992). Quantifying sonochemistry: casting some light on a 'black art'. Ultrasonics, 30, $40-42$.

Mason, T. J. (1990). Sonochemistry: the uses of ultrasound in chemistry. Cambridge, England: Royal Society of Chemistry.

Mason, T. J. (1991). Practical sonochemistry user's guide to application in chemistry and chemical engineering. New York: Ellis Horwood. 
545 Mason, T. J., Lorimer, J. P., Baters, D. M. \& Zhao, Y. (1994). Dosimetry in sonochemistry: the use of aqueous terephthalate ion as a fluorescence monitor. Ultrasonics Sonochemistry, 1, 91-95

Mason, T.J. \& Lorimer, J.P. (2002). Applied sonochemistry, Wiley-VCH, Verlag GmbH, Weinheim.

Mason, T.J. (1998), Power ultrasound in food processing - the way forward. In: M.J.W. Povey and T.J. Mason, Editors, Ultrasound in Food Processing, Thomson Science, London, UK pp. 105-126.

Mason, T.J., Paniwnyk, L. and Lorimer, J.P. (1996). The uses of ultrasound in food technology, Ultrasonics Sonochemistry, 3, 253-260.

McClements, J. (1995). Advances in the application of ultrasound in food analysis and processing, Trends in Food Science and Technology, 6, 293-299.

Mead, E.L., Sutherland, R.G. and Verrall, R.E. (1976). The effect of ultrasound on water in the presence of dissolved gases. Canadian Journal of Chemistry, 54, 1114-1120.

Min, S., Min, S.K. and Zhang, Q.H. (2003). Inactivation kinetics of tomato juice lipoxygenase by pulsed electric fields, Journal of Food Science 68, 1995-2001.

Özbek, B., \& Ülgen, K. (2000). The stability of enzymes after sonication. Process Biochemistry, 35(9), 1037-1043.

Piyasena, P., Mohareb, E., \& McKellar, R.C. (2003). Inactivation of microbes using ultrasound: a review. International Journal of Food Microbiology, 87, 207- 216

Raharintsoa, C., Gaulard, M. L. \& Alais, C. (1977). Etude de l'action des ultrasons cavitans sur quelques enzymes coagulantes. Lait, 57, 631-645.

Raharintsoa, C., Gaulard, M. L. \& Alais, C. (1978). Effet des ultrasons cavitans sur la coagulation du lait par les enzymes. Lait, 58, 559-574. 
569 Raso, J., Manas, P., Pagan, R., \& Sala, F.J.(1999). Influence of different factors on the output power transferred into medium by ultrasound. Ultrasonics Sonochemistry, 5, 157-162.

Ratoarinoro, C., Contamine, F., Wilhem, A. M., Berlan, J., \& Delmas, H. (1995). Power measurement in Sonochemistry. Ultrasonics Sonochemistry, 2(1), 43 - 47.

Raviyan, P., Zhang, Z. \& Feng, H. (2005). Ultrasonication for tomato pectinmethylesterase inactivation: effect of cavitation intensity and temperature on inactivation. Journal of Food Engineering, 70, 189-196.

Sakakibara, M. Wang, D. Takahashi, R., Takahashi , K and Mori, S. (1996). Influence of ultrasound irradiation on hydrolysis of sucrose catalyzed by invertase. Enzyme and Microbial Technology, 18(1), 444-448.

Sala, F.J., Burgos, J., Condon, S., Lopez, P., \& Raso, J.(1995). Effect of heat and ultrasounds on microorganisms and enzymes. In: G. W. Gould, New Methods of Food Preservation, pp. 176 - 204. Glasgow: Blackie.

Salleh-Mack, S. Z. \& Roberts, J. S. (2007). Ultrasound pasteurization: The effects of temperature soluble solids organic acids and $\mathrm{pH}$ on the inactivation of Escherichia coli ATCC 25922. Ultrasonics Sonochemistry, 14, 323-329.

Sams, A.R., Feria, R., (1991). Microbial effects of ultrasonication of broiler drumstick skin. Journal of Food Science, 56 (1), 247- 248.

Santamaria, L., Castellani, A, \& Levi, F. A. (1952). Hyaluronidase inactivation by ultrasonic waves and its mechanism. Enzymologia, 15(5), 285-295.

Şener, N., Apar, D. K. \& Özbek, B (2006). A modelling study on milk lactose hydrolysis and $\beta$-galactosidase stability under sonication. Process Biochemistry, 41(7), 1493-1500.

Seymour, I.J., Burfoot, D., Smith, R.L., Cox, L.A., Lockwook, A., (2002). Ultrasound decontamination of minimally processed fruits and vegetables. International Journal of Food Science \& Technology, 37, 547- 557. 
594 Snir, R., Koehler, P. E., Sims, K. A., Wicker, L. (1995). pH and cations influence permeability of marsh white grapefruit pectinesterase on polysulfone ultrafiltration membrane. Journal of Agricultural Food Chemistry, 43, 1157-1162

Stead, D (1986). Microbial lipases - their characteristics, role in food spoilage and industrial 598 uses. Journal of Dairy Research, 53(3), 481-505.

Suslick, K. S.(1988) Ultrasounds: Its Chemical Physical and Biological Effects VHC 600 Publishers New York. suspension by ultrasonic cavitation. Nahrung, 41(5), 299-301.

Technologies, doi:10.1016/j.ifset.2008.11.006.

Tiwari, B.K., O'Donnell, C.P., Muthukumarappan, K. and Cullen, P.J. (2008). Effect of ultrasound processing on the quality and nutritional properties of fruit juices. Stewart Postharvest Review 4(5): 1-6.

Tiwari, B.K., O’Donnell, C.P., Muthukumarappan, K., \& Cullen, P.J. (2009b) Effect of sonication on orange juice quality parameters during storage. International Journal of Food Science and Technology, 44(3), 586-595.

Tiwari, B.K., O’Donnell, C.P., Patras, A., Brunton, N.P., \& Cullen, P.J. (2009a). Effect of ozone processing on anthocyanins and ascorbic acid degradation of strawberry juice, Food Chemistry, 113(4), 1119-1126.

Tsukamoto, I., Yim, B., Stavarache, C. E., Furuta, M., Hashiba, K. and Maeda, Y. (2004). Inactivation of Saccharomyces cerevisiae by ultrasonic irradiation. Ultrasonic Sonochemistry, 11, 61-65. 
620 Ugarte-Romero, E., Feng, H., Martin, S. E., Cadwallader, K.R. \& Robinson, S. J. (2006). Inactivation of Escherichia coli with power ultrasound in apple cider. Journal of Food Science, 71, 102-108.

Valero, M., Recrosio, N., Saura, D., Munoz, N., Martic, N. \& Lizama, V. (2007). Effects of ultrasonic treatments in orange juice processing. Journal of Food Engineering, 80, 625 $509-516$.

Van den Broeck, I., Ludikhuyze, L. R., van Loey, A. M., \& Hendrickx, M. E. (2000). Inactivation of orange pectinesterase by combined high-pressure and temperature treatments: a kinetic study. Journal of Agriculture \& Food Chemistry, 48, 1960 - 70.

Vercet, A., Burgos, J., Crelier, S., \& Lopez-Buesa, P. (2001). Inactivation of proteases and 630 lipases by ultrasound, Innovative Food Science and Emerging Technologies, 2, 139150.

Vercet, A., Lopez, P. \& Burgos, J. (1997). Inactivation of heat-resistant lipase and protease from Pseudomonas fluorescens by manothermosonication. Dairy Science, 80, 29-36. $47,432-437$.

Vercet, A., López, P., Burgos, J. (1997). Inactivation of heat-resistant lipase and protease 640 Vercet, A., Oria, R., Marquina, P., Crelier, S. and Lopez-Buesa, P. (2002). Rheological from Pseudomonas fluorescens by manothermoultrasonication. Journal of Dairy properties of yoghurt made with milk submitted to manothermosonication. Journal of Agricultural and Food Chemistry, 50(21), 6165-6171. 
643 Villamiel, M. \& de Jong, P. (2000). Influence of high-intensity ultrasound and heat treatment 644 in continuous flow on fat, proteins and native enzymes of milk. Journal of 645 Agricultural and Food Chemistry, 48, 472-478.

646 Villamiel, M., van Hamerveld, E. H. and de Jong, P. (1999). Review: Effect of ultrasound 647 processing on the quality of dairy products. Milchwissenschaft, 54, 69-73.

648 Wu, H., Hulbert, G. J. and Mount, J. R. (2001). Effects of ultrasound on milk homogenisation 649 and fermentation with yoghurt starter. Innovative Food Science and Emerging Technologies, 211-218.

651 Wu, J., Gamage, T.V., Vilkhu, K.S., Simons, L.K. and Mawson , R. (2008). Effect of 652 653 Emerging Technologies, 9(2), 186-195.

654 Yemenicioglu, A. \& Cemeroglu, B. (2003). Consistency of polyphenol oxidase (PPO) 655 thermostability in ripening apricots (Prunus armeniaca L.): evidence for the presence 656 of thermostable PPO forming and destabilizing mechanisms in apricots. Journal of 657 Agricultural and Food Chemistry, 51(8), 2371-2379.

658 